\title{
Soil applications of NPK affect fruit quality and shelf-life of 'Cristalina' cactus pear
}

\author{
Jorge A. Zegbe ${ }^{\star}$, Alfonso Serna-Pérez and Jaime Mena-Covarrubias \\ Instituto Nacional de Investigaciones Forestales, Agrícolas y Pecuarias, Campo Experimental Zacatecas, Apartado Postal No. 18, \\ Calera de Víctor Rosales, Zacatecas, 98500, México
}

Received 28 December 2014 - Accepted 27 May 2015

\begin{abstract}
Introduction. Studies of NPK application in cactus pear have focused on their effects on fruit yield and quality at harvest. Their effects on fruit postharvest life have been neglected. Our objective was therefore to study the influence of soil-applied NPK on some fruit quality attributes after three or four weeks of storage at room conditions for 'Cristalina' cactus pear. Materials and methods. The experiment was carried out in a commercial orchard in 2004, 2005, and 2006. Application rates were: 0, 30, 60, and $90 \mathrm{~kg} \mathrm{~N} \mathrm{ha}{ }^{-1} ; 0,30,45$, and $60 \mathrm{~kg} \mathrm{P}^{-1}$, and 0 , 30 , and $60 \mathrm{~kg} \mathrm{~K} \mathrm{ha}^{-1}$. These rates were arranged in an incomplete factorial matrix in a randomised complete block design with three replications. Nine fruit per treatment (three per replication) were randomly harvested and stored for three or four weeks at room temperature. The measured fruit quality parameters were: weight, pulp to peel ratio, flesh firmness (FF), total soluble solids concentration (TSSC), dry matter concentration of pulp (DMCP), and fruit weight loss (FWL). Results and discussion. After storage, FF was the same among treatments for all years. The TSSC and DMCP were similar among treatments but tended to be lower with high rates of $\mathrm{N}$. The rate of $90 \mathrm{~kg} \mathrm{~N}^{-1}$ increased the FWL. Conclusion. NPK applications produced inconsistent results; therefore, further research is needed in order to address the fruit quality of cactus pear as key for marketing and for consumers' acceptance.
\end{abstract}

Keywords: Mexico / cactus pear / Opuntia albicarpa / firmness / fruit weight loss / shelf life

Résumé - L'application au sol de NPK affecte la qualité et la durée de vie des fruits des figues de barbarie cv. 'Cristalina'. Introduction. Les études de fertilisation NPK du figuier de Barbarie ont généralement porté sur leurs effets sur le rendement et sur la qualité des fruits à la récolte. L'impact sur la qualité des fruits post-récolte a été négligé. C'est pourquoi notre objectif était d'étudier l'influence de la fertilisation NPK appliquée au sol sur certains critères qualitatifs des fruits mesurés après 3 ou 4 semaines de stockage à température ambiante. Matériel et méthodes. L'expérience a été réalisée dans un verger commercial (cv. 'Cristalina') en 2004, 2005 et 2006. Les doses d'application correspondent à $0,30,60$ et $90 \mathrm{~kg} \mathrm{~N} \mathrm{ha}^{-1} ; 0,30,45$ et $60 \mathrm{~kg} \mathrm{P}^{-1}$; et 0,30 , et $60 \mathrm{~kg} \mathrm{~K} \mathrm{ha}^{-1}$. Ces doses ont été apportées selon un dispositif matriciel factoriel incomplet en blocs randomisés à trois répétitions. Neuf fruits par traitement (3 par répétition) ont été récoltés et stockés de façon aléatoire pendant 3 ou 4 semaines à température ambiante. Les paramètres suivants de qualité du fruit ont été mesurés : poids, rapport pulpe/peau, fermeté de la chair (FF), concentration en matières solubles (TSSC), teneur en de matière sèche de la pulpe (DMCP), et perte de poids des fruits (FWL). Résultats et discussion. Après stockage, FF était le même pour tous les traitements et quelque soit l'année. TSSC et DMCP étaient comparables entre traitements, mais avaient tendance à être plus faibles pour des doses de N élevées. La dose de $90 \mathrm{~kg} \mathrm{~N} \mathrm{ha}^{-1}$ a fortement augmenté la FWL. Conclusion. L'application de NPK sur les cultures de figues de Barbarie a produit des résultats incohérents; des recherches supplémentaires doivent être menées afin de maîtriser les facteurs de la qualité des fruits du figuier de Barbarie, la composante-clé pour le développement du marché et de la consommation.

Mots clés : Mexique / figue de Barbarie / Opuntia albicarpa / fermeté / perte de poids / aptitude au stockage

\section{Introduction}

Cactus pear fruit (Opuntia albicarpa) is a native Mexican fruit also called 'tuna'. On average, $0.49 \mathrm{Mt}$ are annually harvested in more than 55,000 ha in the semi-arid highlands

\footnotetext{
* Corresponding author: jzegbe@zacatecas.inifap.gob.mx
}

of central and north-central Mexico. This plant, adapted to arid and semi-arid environment, exhibits the crassulacean acid metabolism [1]. It is therefore, highly efficient in water use and biomass production [1-3]. As fodder, vegetable, and fruit, cactus pear is now cultivated in Europe, America, Asia, and Africa $[4,5]$. 
For fruit production cactus pear needs management practices such as pest, disease, and weed control; pruning, thinning, irrigation, and organic/mineral nutrition [6,7]. Organic and mineral nutrition research has focused on effects on yield, fruit size, fruit quality [2, 8-13], and off-season fruit yield [14-18]. Some reports have shown no effect of soil applications of NPK (nitrogen, phosphorous and potassium) either on yield $[8,10,12]$ or on some fruit quality attributes at harvest $[10,12]$. Fruit sugar concentration has been an exception [10]. The latter authors found higher sugar concentration in fruit from NPK-fertilized plants than from unfertilized ones. They concluded that cladode magnesium concentration significantly influences fruit sugar concentration.

In stone fruit, the influence of orchard management practices, especially irrigation and mineral nutrition, have had strong influence on postharvest fruit quality $[19,20]$. However, little [21] or no attention has been paid to the effect of soil application of NPK on fruit quality after storage period for this fruit. For instance, several $\mathrm{N}$ fertilization rates (from 0 to $300 \mathrm{~kg} \mathrm{ha}^{-1}$ ) were studied for their effect on postharvest fruit quality of 'Amarilla sin espinas' [21]. The latter authors found that fruit firmness decreased and fungal damage increased after 14 days in storage at room conditions as $\mathrm{N}$ fertilization rates increased. To our knowledge, there is no more information on this topic which is important for its implication on fruit storability potential, shipment to distant markets, and consumer acceptance. The objective of this research was to study the influence of soil-applied NPK on some fruit quality attributes after three or four weeks of storage at room conditions for 'Cristalina' cactus pear. We expected that at least some of the NPK rates could delay fruit weight loss and therefore, would maintain fruit quality.

\section{Materials and methods}

\subsection{Experimental site, plant material, and orchard management}

The study was carried out in a commercial orchard established in a semi-arid region of north central México (lat. $22^{\circ} 32^{\prime} \mathrm{N}$, long. $103^{\circ} 03^{\prime} \mathrm{W}$, elevation $1,976 \mathrm{~m}$ asl). The annual mean temperature, cumulative precipitation, and pan evaporation were $25.7{ }^{\circ} \mathrm{C}, 482 \mathrm{~mm}$, and $2245 \mathrm{~mm}$, respectively, with most of the rainfall (62\%) falling in summer [22]. The soil is classified as Fluvisol [23], and it has a sandy-loam to loam texture with a $\mathrm{pH}$ from 6.1 to 7.4 , organic matter content from 1.00 to $1.56 \%$, and cation exchange capacity from 13.8 to $26.5 \mathrm{meq} 100 \mathrm{~g}^{-1}$ soil. Soil fertility analysis, before the fertilizers were applied, indicated a total concentration of $0.71 \mathrm{mg} \mathrm{kg}-1$ inorganic- $\mathrm{N}$ and a total- $\mathrm{N}$ of $10 \mathrm{mg} \mathrm{kg}^{-1}$. The concentration range for some other macronutrient elements was: $2.0-3.2 \mathrm{mg} \mathrm{P} \mathrm{kg}-1,520-1,173 \mathrm{mg} \mathrm{K} \mathrm{kg}^{-1}$, 1,834-4,440 $\mathrm{mg} \mathrm{Ca} \mathrm{kg}^{-1}$, and 213-334 $\mathrm{mg} \mathrm{Mg} \mathrm{kg}^{-1}$ soil.

The orchard of 4-year-old cactus pear plants (Opuntia albicarpa Scheinvar) cv. 'Cristalina', a late-maturing and whitepulped cultivar, was planted in rows separated at $4 \mathrm{~m}$ and $3 \mathrm{~m}$ between plants and trained to an open vase system. Tilling between rows and by hand pulling and hoe cultivation around
Table I. Mineral nutrition treatments applied to 'Cristalina' cactus pear plants for three consecutive growing seasons from 2004 to 2006 in Jerez, Zacatecas, Mexico.

\begin{tabular}{cccc}
\hline & \multicolumn{3}{c}{ Mineral nutrient rates $\left(\mathrm{kg} \mathrm{ha}^{-1}\right)$} \\
\cline { 2 - 4 } Treatment number & Nitrogen & Phosphorus & Potassium \\
\hline 1 & 0 & 0 & 0 \\
2 & 0 & 30 & 30 \\
3 & 30 & 30 & 30 \\
4 & 60 & 30 & 30 \\
5 & 90 & 30 & 30 \\
6 & 60 & 45 & 30 \\
7 & 60 & 60 & 30 \\
8 & 60 & 30 & 0 \\
9 & 60 & 30 & 60 \\
10 & 90 & 60 & 60 \\
\hline
\end{tabular}

trees controlled weeds. Cultural practices used in cactus pear local production included cladode pruning, furrow irrigation, and pest control. Size and uniformity of fruit was promoted by manual fruit thinning (24). In dry season (April to June) irrigation water was applied 4 to 5 times and an additional one 2 weeks after harvesting (September or October) for applying the second half of the nitrogen dose as explained below.

\subsection{Mineral nutrient treatments, experimental design, and fertilization program}

The NPK fertilization was applied in 10 different combinations (treatments) arranged as an incomplete factorial matrix (table I). The rates (in $\mathrm{kg} \mathrm{ha}^{-1}$ ) were: $0,30,60$, and $90 \mathrm{~N} ; 0$, 30,45 , and $60 \mathrm{P}$; and 0,30 , and $60 \mathrm{~K}$. In the field, treatments were applied in a randomised complete block design with three replicates. Every experimental unit had 5 consecutive plants in a row. Half of the $\mathrm{N}$ and all of the $\mathrm{P}$ and $\mathrm{K}$ of every fertilization treatment were applied with the irrigation water at the beginning of the blooming stage, on 6 April 2004, 19 April 2005, and 21 April 2006. The remaining dose of $\mathrm{N}$ was applied 2 weeks after fruit harvest with watering on 19 October in both 2004 and 2005 and on 22 September in 2006. The sources for $\mathrm{N}$, P, and $\mathrm{K}$ were ammonium sulphate, triple superphosphate, and potassium chloride, respectively.

\subsection{Fruit data collection}

The fruits were collected at export harvest maturity (yellowish-green) from the two central plants of each plot. To assess fruit quality after storage conditions, 9 uniformly sized fruits per treatment ( 3 per replication) were randomly picked at the fourth harvesting time from the outer part and around the plants. This was done on 5 October 2004, 15 September 2005, and 21 August 2006. Fruit quality assessment was recorded after 3 to 4 weeks of storage at room temperature and relative humidity conditions, mimicking growers' commercial storage. These assessments were done on 3 November 2004, 7 October 2005, and 18 September 2006. 
Table II. Effect of mineral nutrition treatments (MNT) on final fruit weight and weight loss after 3 to 4 weeks of storage at room conditions for 'Cristalina' cactus pear in Jerez, Zacatecas, Mexico. Values of vapour pressure deficit for 2004, 2005, and 2006 were $\approx 1.3,0.9$, and $0.8 \mathrm{kPa}$, respectively. Mean separations within a column were by Tukey's minimum significant difference (MSD) at $P \leqslant 0.05(n=9)$.

\begin{tabular}{|c|c|c|c|c|c|c|c|c|c|}
\hline \multirow[b]{2}{*}{ MNT } & \multicolumn{3}{|c|}{$\begin{array}{c}\text { Mineral } \\
\text { nutrient rates } \\
\left(\mathrm{kg} \mathrm{ha}^{-1}\right)\end{array}$} & \multicolumn{3}{|c|}{ Fruit weight (g) } & \multicolumn{3}{|c|}{ Fruit weight loss (\%) } \\
\hline & $\mathrm{N}$ & $\mathrm{P}$ & $\mathrm{K}$ & 2004 & 2005 & 2006 & 2004 & 2005 & 2006 \\
\hline 1 & 0 & 0 & 0 & $162.6 \mathrm{~b}$ & $178.8 \mathrm{a}$ & $182.4 \mathrm{a}$ & $6.0 \mathrm{a}$ & $11.8 \mathrm{a}$ & $4.6 \mathrm{ab}$ \\
\hline 2 & 0 & 30 & 30 & $184.5 b$ & $165.3 \mathrm{a}$ & $201.4 \mathrm{a}$ & $6.2 \mathrm{a}$ & $8.80 \mathrm{a}$ & $4.2 \mathrm{~b}$ \\
\hline 3 & 30 & 30 & 30 & $190.3 \mathrm{ab}$ & $174.3 \mathrm{a}$ & 201.9a & $4.6 \mathrm{a}$ & $12.3 \mathrm{a}$ & $4.6 \mathrm{ab}$ \\
\hline 4 & 60 & 30 & 30 & $221.4 \mathrm{ab}$ & $178.3 \mathrm{a}$ & $188.7 \mathrm{a}$ & $4.5 \mathrm{a}$ & $11.7 \mathrm{a}$ & $4.7 \mathrm{ab}$ \\
\hline 5 & 90 & 30 & 30 & $250.6 \mathrm{a}$ & $187.4 \mathrm{a}$ & $187.7 \mathrm{a}$ & $4.3 \mathrm{a}$ & $10.0 \mathrm{a}$ & $6.3 \mathrm{a}$ \\
\hline 6 & 60 & 45 & 30 & $218.2 \mathrm{ab}$ & $192.8 \mathrm{a}$ & $195.1 \mathrm{a}$ & $4.7 \mathrm{a}$ & $9.90 \mathrm{a}$ & $4.6 \mathrm{ab}$ \\
\hline 7 & 60 & 60 & 30 & $218.1 \mathrm{ab}$ & $177.5 \mathrm{a}$ & $211.7 \mathrm{a}$ & $5.5 \mathrm{a}$ & $11.1 \mathrm{a}$ & $4.8 \mathrm{ab}$ \\
\hline 8 & 60 & 30 & 0 & $211.4 \mathrm{ab}$ & $196.6 \mathrm{a}$ & $185.1 \mathrm{a}$ & $5.0 \mathrm{a}$ & $9.40 \mathrm{a}$ & $4.3 b$ \\
\hline 9 & 60 & 30 & 60 & $220.8 \mathrm{ab}$ & $181.9 \mathrm{a}$ & $187.1 \mathrm{a}$ & $5.0 \mathrm{a}$ & $11.8 \mathrm{a}$ & $4.4 \mathrm{ab}$ \\
\hline 10 & 90 & 60 & 60 & $206.3 \mathrm{ab}$ & $171.6 \mathrm{a}$ & $191.4 \mathrm{a}$ & 7.1a & $12.0 \mathrm{a}$ & $5.1 \mathrm{ab}$ \\
\hline \multicolumn{4}{|c|}{ Significance } & 0.01 & 0.1 & 0.7 & 0.3 & 0.2 & 0.04 \\
\hline \multicolumn{4}{|c|}{$M S D$} & 64.1 & 35.4 & 58.0 & 4.3 & 3.7 & 1.8 \\
\hline
\end{tabular}

\subsection{Fruit quality assessment}

Several fruit quality attributes were measured after storage: flesh firmness (FF), total soluble solids concentration (TSSC), pulp and peel weights, and dry matter concentration of pulp (DMCP) [25]. Briefly, fruits were individually weighed and after removing fruit skin, two FF measurements (in $\mathrm{N}$ ) were performed on 2 opposite sides in the middle of each fruit using a press-mounted penetrometer (FT 327, Wagner Instruments, Greenwich, CT, USA). The TSS concentration (in ${ }^{\circ}$ Brix) was measured using a digital refractometer (PR-32 $\alpha$, Atago, CO., ltd., Tokyo, Japan) calibrated before each reading. For each fruit, pulp and peel were separated and distinctly weighed (Mettler PE11, Mettler Instrumente, Greifensee-Zurich, Switzerland). The DMCP (in $\mathrm{mg} \mathrm{g}^{-1}$ fresh weight) was determined from 25 -g composite samples of fresh pulp from 3 fruits (per replicate) and oven-dried at $65^{\circ} \mathrm{C}$ to constant weight.

Fruit weight loss (in \%) was evaluated at weekly intervals for 3 to 4 weeks by weighing fruit individually with a precision scale (Mettler PE11, Mettler Instrument, GreifenseeZurich, Switzerland). In 2004 the storage conditions at room temperature were $20.0 \pm 1.0^{\circ} \mathrm{C}$ and relative humidity $44 \pm 7 \%$ [vapour pressure deficit $(\mathrm{VPD}) \approx 1.3 \mathrm{kPa}$ ]. The corresponding values in the same order for 2005 and 2006 were $15.0 \pm 1.0^{\circ} \mathrm{C}$ and $47 \pm 10 \%(\mathrm{VPD} \approx 0.9)$, and $15.0 \pm 0.8{ }^{\circ} \mathrm{C}$ and $53 \pm 3 \%$ $(\mathrm{VPD} \approx 0.8)$, respectively.

\subsection{Data analysis}

The data were analysed through a randomised complete block model using the GLM procedure of SAS software (version 9.2; SAS Institute, Cary, NC). The NPK combinations were analysed as treatments. Treatment means were separated by the Tukey's studentised range test at $P \leqslant 0.05$. Main effect of $\mathrm{N}, \mathrm{P}$ or K was analysed separately.

The use of an incomplete matrix of factor levels is a statistical strategy to reduce the dimensions of the experiment.
However, this technique cannot be used to test the null hypothesis over the interaction among factor levels [26]. Therefore, the data on each quality parameter was firstly analysed as treatments. Secondly, when some significant difference was detected, the main effect of N, P or K was explored separately to establish its particular relevance over each quality attribute.

\section{Results and discussion}

\subsection{Fruit weight loss as main treatment effect}

In 2004, after 4 weeks of storage at room conditions, there was a significant treatment effect on fruit size in terms of fruit weight $(P \leqslant 0.05)$. Treatment $5(90 \mathrm{~N}-30 \mathrm{P}-30 \mathrm{~K})$ and control $(0 \mathrm{~N}-\mathrm{OP}-0 \mathrm{~K})$ produced the highest and the lowest fruit weight respectively. However, fruit size was the same among the treatments in 2005 and 2006 (table II). These results were consistent with those observed at harvest in this experiment [25]. The effect can be attributed to a competition for assimilates among fruit [27]. At the start of the 2004 experiment there was lesser amount of fruit in all treatments compared with 2005 and 2006 growing seasons. Therefore, a higher fruit sink strength, partitioning of assimilates among fruits resulted in more uniform sized-fruit in all treatments.

After harvest, fruit weight loss (FWL) is the major cause of fruit deterioration during storage [28]. This is because cactus pear fruit continue to transpire resulting in shrivelling and loss of marketability [29]. However, the final size and shelf life of cactus pear fruit depend on orchard management practices during the growing season $[19,20]$ and post-harvest handling [30]. In our experiment, after 3 to 4 weeks of storage at room conditions, FWL was not affected by the treatments in 2004 and 2005. In cactus pear the FWL should be higher than $8 \%$ for shrivel symptoms to be observed [30]. This only occurred in 2005 due to a severe fungi attack that could speed up FWL; in fact, the fruit could not be stored for more than three weeks. In 2006, Treatment 5 (90N-30P-30K) increased FWL by $\approx 38 \%$ 
Table III. Main effect of nitrogen, phosphorous, and potassium on final fruit weight loss (in \%) after 3 to 4 weeks of storage at room conditions for 'Cristalina' cactus pear in Jerez, Zacatecas, Mexico. Values of vapour pressure deficit for 2004, 2005, and 2006 were $\approx 1.3$, 0.9 , and $0.8 \mathrm{kPa}$, respectively. Mean separations within a column were by Tukey's minimum significant difference (MSD) at $P \leqslant 0.05$.

\begin{tabular}{lccc}
\hline Fertilization rates & \multicolumn{3}{c}{ Fruit weight loss (\%) } \\
& 2004 & 2005 & 2006 \\
\hline \multicolumn{1}{c}{ Nitrogen $\left(\mathrm{kg} \mathrm{ha}^{-1}\right)$} & & & \\
\hline 0 & $6.3 \mathrm{a}$ & $10.4 \mathrm{a}$ & $4.4 \mathrm{~b}$ \\
30 & $4.6 \mathrm{a}$ & $12.3 \mathrm{a}$ & $4.6 \mathrm{~b}$ \\
60 & $4.9 \mathrm{a}$ & $10.8 \mathrm{a}$ & $4.6 \mathrm{~b}$ \\
90 & $5.7 \mathrm{a}$ & $11.0 \mathrm{a}$ & $5.7 \mathrm{a}$ \\
\hline Significance & 0.08 & 0.07 & 0.002 \\
MSD & 2.1 & 2.0 & 0.7 \\
\hline Phosphorus $\left(\mathrm{kg} \mathrm{ha}^{-1}\right)$ & & & \\
\hline 0 & $6.5 \mathrm{a}$ & $11.8 \mathrm{a}$ & $4.6 \mathrm{a}$ \\
30 & $4.9 \mathrm{a}$ & $10.7 \mathrm{a}$ & $4.8 \mathrm{a}$ \\
45 & $4.7 \mathrm{a}$ & $09.9 \mathrm{a}$ & $4.6 \mathrm{a}$ \\
60 & $6.3 \mathrm{a}$ & $11.5 \mathrm{a}$ & $4.9 \mathrm{a}$ \\
\hline Significance & 0.52 & 0.39 & 0.88 \\
MSD & 5.5 & 3.6 & 1.9 \\
\hline Potassium $\left(\mathrm{kg} \mathrm{ha}^{-1}\right)$ & \multicolumn{3}{c}{} \\
\hline 0 & $5.7 \mathrm{a}$ & $10.6 \mathrm{a}$ & $4.4 \mathrm{a}$ \\
30 & $5.0 \mathrm{a}$ & $10.7 \mathrm{a}$ & $4.9 \mathrm{a}$ \\
60 & $5.0 \mathrm{a}$ & $11.9 \mathrm{a}$ & $4.8 \mathrm{a}$ \\
\hline Significance & 0.20 & 0.35 & 0.41 \\
MSD & 2.0 & 3.0 & 1.1 \\
\hline
\end{tabular}

$(P \leqslant 0.05)$ compared with the control and Treatments 2 and 8. The other treatments had an intermediate FWL (table II). To minimize FWL during storage is commercially important for long-term storage and long-distance transport to markets [28].

The main effects of N, P, and $\mathrm{K}$ were also separately studied. The application rates of $\mathrm{P}$ and $\mathrm{K}$ did not alter FWL over the 3 cropping seasons while those of $\mathrm{N} \operatorname{did}(P=0.002)$ in 2006 (table III). The rate of $90 \mathrm{~kg} \mathrm{~N} \mathrm{ha}^{-1}$ increased significantly FWL in relation to 0,30 and $60 \mathrm{~kg} \mathrm{~N} \mathrm{ha}^{-1}$. In apple, fruit water loss is positively correlated with their size and surface area [31]. Here, the FWL arcsine-transformed data did not correlate with the weights of fruit $(r=-0.16 ; P=0.14)$, peel $(r=-0.18 ; P=0.09)$, and pulp $(r=-0.01 ; P=0.93)$. The removal of glochids (spines) from cactus pear fruit increases FWL during storage [30]. We did not remove spines from the fruit. Then, some cuticular alterations might have been induced at the highest $\mathrm{N}$ rate leading to increase FWL. However, further epicuticular studies are needed for confirmation.

\subsection{Fruit firmness poorly related to $\mathrm{N}$ and $\mathrm{P}$}

After 3 to 4 weeks of storage fruit firmness was maintained without measurable changes among treatments in all years (table IV). This is in contrast to another study on mineral nutrition of cactus pear [21]. In the first two years of this study, pulp to peel ratio (PPR) was similarly maintained among treatments along the storage period. In 2006 however, PPR was significantly higher in Treatment 8 (60N-30P-0K) and $10(90 \mathrm{~N}-60 \mathrm{P}-60 \mathrm{~K})$ than in the control. Except for the main effects of $\mathrm{N}(P=0.05)$ and $\mathrm{P}(P=0.05), \mathrm{K}(P=0.6)$ did not influence PPR. The main effect of $\mathrm{N}$ revealed a trend to increase PPR as the rate of $\mathrm{N}$ increased. The PPR values (minimum significant difference (MSD) $=0.431 ; P=0.05$ ) were $1.5,1.5,1.8$, and 1.8 for $0,30,60$, and $90 \mathrm{~kg} \mathrm{~N} \mathrm{ha}^{-1}$, respectively. On the other hand, the main effect of $\mathrm{P}$ pointed out that $45 \mathrm{~kg} \mathrm{P} \mathrm{ha}^{-1}$ was higher than the control. The PPR values $(\mathrm{MSD}=0.4 ; P=0.04$ ) were $1.3,1.7,1.8$, and 1.7 for 0 , 30,45 , and $60 \mathrm{~kg} \mathrm{P}^{-1}$, respectively. Although peel thickness was not measured, higher PPR could be due to decreases in peel thickness, in terms of weight; hence higher PPR in the rates of $\mathrm{N}$ and $\mathrm{P}$.

\subsection{Total soluble solids and dry matter concentrations of fruit}

Total soluble solids concentration (TSSC) showed an inconsistent response after 3 to 4 weeks of storage under room conditions. In 2004, control fruit maintained higher TSSC compared with other treatments (table IV). Although not significant, a similar trend was observed in 2005. In contrast, Treatment $4(60 \mathrm{~N}-30 \mathrm{P}-30 \mathrm{~K})$ and control and Treatment 7 (60N-60P-30K) registered the highest and lowest values of TSSC, respectively while the other treatments had an intermediate response in 2006 (table IV). The main effect of $\mathrm{P}$ revealed that the rates $\left(\mathrm{kg} \mathrm{ha}^{-1}\right) 30$ and 45 maintained higher TSSC values compared with those of 0 and 60 . The TSSC values $(\mathrm{MSD}=1 \% ; P=0.02)$ were $10.0,11.1,11.2$, and 10.5 for $0,30,45$, and $60 \mathrm{~kg} \mathrm{P}^{-1}$, respectively. Cactus pear fruit exhibit a non-climacteric respiration pattern [32]. However, in similar storage conditions to ours, significant reduction of both TSSC and dry matter concentration of pulp (DMCP) after storage has been observed [33]. In the present experiment, on average, the reduction of TSSC (from harvest to after storage) was $27 \%, 13.0 \%$, and $6.1 \%$ for 2004,2005 , and 2006, respectively. This last trend has been observed in other cactus pear cultivars such as 'Rojo Liso' [33] and 'Amarilla Olorosa' and 'Cristalina' [34] undergoing thinning and irrigation treatments, respectively. Therefore, all these findings might confirm that other unknown metabolic pathways are using the soluble sugars.

After 4 weeks of storage, DMCP was similar among mineral nutrient treatments in 2004. For the years 2005 and 2006, Treatment 5 (90N-30P-30K) had the lowest DMCP values (table IV). The main effect analysis of $\mathrm{N}$ revealed significant influence on DMCP only in 2005. Values of DMCP were reduced with the higher application rates of these nutrients. The DMCP values $\left(\mathrm{mg} \mathrm{g}^{-1}\right.$ fresh weight, MSD = $10.1 ; P=0.001$ ) were $178.8,172.7,170.2$, and 161.8 for 0 , 30,60 , and $90 \mathrm{~kg} \mathrm{~N} \mathrm{ha}^{-1}$, respectively. The DMCP values $(\mathrm{MSD}=9.5 ; P=0.05)$ were $174.8,171.2$, and 164.1 for 0 , 30 , and $60 \mathrm{~kg} \mathrm{~K} \mathrm{ha}^{-1}$. We explored the possibility of a dilution effect due to higher pulp weight in fertilised treatments, but a non-significant and weak correlation between DMCP and pulp weight $(r=-0.13 ; P=0.05)$ was found. Similar to TSSC, on average, a reduction of DMCP after storage was observed over the years of this experiment. The values were $14.4 \%, 8.5 \%$, and $13.3 \%$ for 2004,2005 , and 2006, respectively. Although cactus pear fruit is non-climacteric, the reduction of DMCP 
Table IV. Effect of mineral nutrition treatments (MNT) on flesh firmness (FF), pulp to peel ratio (PPR), total soluble solids concentration (TSSC), and dry matter concentration of pulp (DMCP) after storage at room conditions for 'Cristalina' cactus pear in Jerez, Zacatecas, Mexico. Vapour pressure deficit for 2004, 2005, and 2006 was $\approx 1.3,0.9$, and $0.8 \mathrm{kPa}$, respectively. Mean separations within a column were by Tukey's minimum significant difference (MSD) at $P \leqslant 0.05(n=9)$.

\begin{tabular}{|c|c|c|c|c|c|c|c|c|c|c|c|c|c|c|c|}
\hline \multicolumn{4}{|c|}{$\begin{array}{l}\text { Mineral nutrition rates } \\
\qquad\left(\mathrm{kg} \mathrm{ha}^{-1}\right)\end{array}$} & \multicolumn{3}{|c|}{$\begin{array}{l}\text { FF } \\
(\mathrm{N})\end{array}$} & \multicolumn{3}{|c|}{$\begin{array}{c}\mathrm{PPR} \\
\left(\mathrm{gg}^{-1}\right) \\
\end{array}$} & \multicolumn{3}{|c|}{$\begin{array}{l}\text { TSSC } \\
\left({ }^{\circ} \text { Brix }\right) \\
\end{array}$} & \multicolumn{3}{|c|}{$\begin{array}{c}\text { DMCP } \\
\left.\text { (mg g }{ }^{-1} \text { fresh weight }\right)\end{array}$} \\
\hline MNT & $\mathrm{N}$ & $\mathrm{P}$ & $\mathrm{K}$ & 2004 & 2005 & 2006 & 2004 & 2005 & 2006 & 2004 & 2005 & 2006 & 2004 & 2005 & 2006 \\
\hline 1 & 0 & 0 & 0 & $27.4 a$ & $26.7 \mathrm{a}$ & $37.8 \mathrm{a}$ & $1.5 \mathrm{a}$ & $1.6 \mathrm{a}$ & $1.3 \mathrm{~b}$ & $9.4 a$ & $11.0 \mathrm{a}$ & $10.0 \mathrm{~b}$ & $157.9 a$ & $180.0 \mathrm{a}$ & $162.7 \mathrm{ab}$ \\
\hline 2 & 0 & 30 & 30 & $29.0 \mathrm{a}$ & $25.5 \mathrm{a}$ & $35.4 \mathrm{a}$ & $1.4 \mathrm{a}$ & $1.5 \mathrm{a}$ & $1.6 \mathrm{ab}$ & $8.3 \mathrm{ab}$ & $10.0 \mathrm{a}$ & $11.3 \mathrm{ab}$ & $162.4 \mathrm{a}$ & $177.5 \mathrm{a}$ & $166.7 \mathrm{ab}$ \\
\hline 3 & 30 & 30 & 30 & $29.2 \mathrm{a}$ & $23.4 \mathrm{a}$ & $30.0 \mathrm{a}$ & $1.5 \mathrm{a}$ & $1.8 \mathrm{a}$ & $1.5 \mathrm{ab}$ & $8.3 \mathrm{ab}$ & $10.7 \mathrm{a}$ & $10.6 \mathrm{ab}$ & $159.3 \mathrm{a}$ & $172.7 \mathrm{ab}$ & $155.1 \mathrm{ab}$ \\
\hline 4 & 60 & 30 & 30 & $28.2 \mathrm{a}$ & $23.6 \mathrm{a}$ & $30.8 \mathrm{a}$ & $1.6 \mathrm{a}$ & $1.9 \mathrm{a}$ & $1.8 \mathrm{ab}$ & 7.6ab & $10.4 \mathrm{a}$ & $11.6 \mathrm{a}$ & $165.8 \mathrm{a}$ & $174.2 \mathrm{ab}$ & $169.5 \mathrm{a}$ \\
\hline 5 & 90 & 30 & 30 & $31.4 \mathrm{a}$ & $22.2 \mathrm{a}$ & $27.6 \mathrm{a}$ & $1.4 \mathrm{a}$ & $2.1 \mathrm{a}$ & $1.8 \mathrm{ab}$ & $6.9 \mathrm{~b}$ & $10.6 \mathrm{a}$ & $10.8 \mathrm{ab}$ & $156.1 \mathrm{a}$ & $158.9 b$ & $146.0 \mathrm{~b}$ \\
\hline 6 & 60 & 45 & 30 & $31.9 \mathrm{a}$ & $26.4 \mathrm{a}$ & $28.2 \mathrm{a}$ & $1.4 \mathrm{a}$ & $1.9 \mathrm{a}$ & $1.8 \mathrm{ab}$ & $6.8 b$ & $9.9 \mathrm{a}$ & $11.2 \mathrm{ab}$ & $150.0 \mathrm{a}$ & $169.4 \mathrm{ab}$ & $153.6 \mathrm{ab}$ \\
\hline 7 & 60 & 60 & 30 & $29.6 a$ & $26.0 \mathrm{a}$ & $35.4 \mathrm{a}$ & $1.6 \mathrm{a}$ & $1.8 \mathrm{a}$ & $1.6 a b$ & $7.5 \mathrm{ab}$ & $9.7 \mathrm{a}$ & $9.9 \mathrm{~b}$ & $153.5 \mathrm{a}$ & $174.4 \mathrm{ab}$ & $149.3 \mathrm{ab}$ \\
\hline 8 & 60 & 30 & 0 & $26.3 \mathrm{a}$ & $30.2 \mathrm{a}$ & $29.9 a$ & $1.6 \mathrm{a}$ & $1.8 \mathrm{a}$ & $1.9 \mathrm{a}$ & $7.6 a b$ & $9.9 \mathrm{a}$ & $11.3 \mathrm{ab}$ & $147.3 \mathrm{a}$ & 169.6ab & $162.1 \mathrm{ab}$ \\
\hline 9 & 60 & 30 & 60 & $28.6 a$ & $26.0 \mathrm{a}$ & $26.5 a$ & $1.5 \mathrm{a}$ & $1.9 \mathrm{a}$ & $1.7 \mathrm{ab}$ & $7.1 \mathrm{~b}$ & $10.1 \mathrm{a}$ & $10.9 \mathrm{ab}$ & $161.5 \mathrm{a}$ & $163.5 \mathrm{ab}$ & $154.7 \mathrm{ab}$ \\
\hline 10 & 90 & 60 & 60 & $27.3 \mathrm{a}$ & $25.1 \mathrm{a}$ & $29.8 \mathrm{a}$ & $1.5 \mathrm{a}$ & $1.9 \mathrm{a}$ & $1.9 \mathrm{a}$ & $6.8 b$ & $10.4 \mathrm{a}$ & $11.1 \mathrm{ab}$ & $157.4 \mathrm{a}$ & $164.7 \mathrm{ab}$ & $156.0 \mathrm{ab}$ \\
\hline \multicolumn{4}{|c|}{ Significance } & 0.4 & 0.3 & 0.06 & 0.3 & 0.2 & 0.03 & 0.01 & 0.2 & 0.01 & 0.06 & 0.005 & 0.03 \\
\hline \multicolumn{4}{|c|}{$M S D$} & 8.4 & 10.0 & 12.6 & 0.4 & 0.7 & 0.5 & 2.3 & 1.7 & 1.4 & 21.0 & 16.6 & 22.4 \\
\hline
\end{tabular}

indicates that part of the carbohydrates was consumed during the storage period, what still needs to be assessed.

\section{Conclusion}

After three years of postharvest evaluations, the effect of mineral nutrition treatments on some quality attributes of cactus pear fruit is still not clear. Fruit weight was maintained higher in Treatment 5 (90N-30P-30K) than in the other treatments only in 2004. In 2006, fruit weight loss increased with $90 \mathrm{~kg} \mathrm{~N} \mathrm{ha}^{-1}$ but $\mathrm{P}$ and $\mathrm{K}$ did not influence fruit weight loss. Fruit firmness was the same among treatments in the three years of this experiment. Mixed results were shown for treatment effects on pulp to peel ratio, total soluble solids concentration, and dry matter concentration of pulp. Further studies on cactus pear are needed to understand the metabolic processes affecting fruit quality at harvest and after storage.

Acknowledgements. This research work was funded in part by The Fundación Produce Zacatecas A.C., No. Ref.: 02/FPZ/2001 and The Consejo Nacional de Ciencia y Tecnología, No. Ref.: 0007-20051_12448. We thank Miguel and Valentín Nava-Félix, the owners of the orchard 'Rancho La Tunera'. Appreciation is extended to Manuel González-Solís, and Jorge Omar Zegbe. We are grateful to Dr. M. Hossein Behboudian (Massey University) for his critical comments on the manuscript. We appreciate the positive comments from the two anonymous Reviewers for improving this document.

\section{References}

[1] Nobel P.S., Achievable productivities of certain CAM plants: basis for high values compared with $\mathrm{C}_{3}$ and $\mathrm{C}_{4}$ plants, New Phytol. 119 (1991) 183-205.

[2] Pimienta-Barrios E., Ramírez-Hernández B.C., Contribuciones al conocimiento agronómico y biológico de los nopales tuneros, Agrociencia 33 (1999) 323-331.
[3] Guevara J.C., Suassuna P., Felker P., Opuntia forage production system: status and prospectus for rangeland application, Rangeland Ecol. \& Manage. 62 (2009) 428-434.

[4] Basile F., Economic aspects of Italian cactus pear production and market, J. Prof. Assoc. Cactus Dev. 4 (2001) 31-46.

[5] Nefzaoui A., Ben Salem H., Cacti: efficient tool for rangeland rehabilitation, drought mitigation and to combat desertification, Acta Hortic. 581 (2002) 295-315.

[6] Pimienta B., E., El nopal tunero, Universidad de Guadalajara, Guadalajara Jalisco, México, 1990.

[7] Inglese P., Orchard planting and management, in: Barbera G., Inglese P., Pimienta-Barrios E. (Eds.), Agro-ecology, cultivation and uses of cactus pear, plant production and protection paper 132, Food and Agriculture Organization of the United Nations, Roma, Italy, 1995.

[8] Gathaara G.N., Felker P., Land M., Influence of nitrogen and phosphorus application on Opuntia engelmanii tissue $\mathrm{N}$ and P concentrations, biomass production and fruit yields, J. Arid Environ. 16 (1989) 337-346.

[9] Claassens A.S., Wessels A.B., The fertilizer requirements of cactus pear (Opuntia ficus-indica) under summer rainfall conditions in South Africa, Acta Hortic. 438 (1997) 83-95.

[10] Karim R., Felker P., Bingam R.L., Correlations between cactus pear (Opuntia spp.) cladode nutrient concentrations and fruit yield and quality, Ann. Arid Zone. 37 (1998) 159-171.

[11] Gugliuzza G., La Mantia T., Inglese P., Fruit load and cladode nutrient concentration in cactus pear, Acta Hortic. 581 (2002) 221-224.

[12] Galizzi F.A., Felker P., González C., Gardiner D., Correlation between soil and cladode nutrient concentrations and fruit yield and quality in cactus pear, Opuntia ficus-indica, in a traditional farm setting in Argentina, J. Arid Environ. 59 (2004) 115-132.

[13] Felker P., Bunch R.A., Mineral nutrition of cactus for forage and fruits, Acta Hortic. 811 (2009) 389-394.

[14] Nerd A., Karady A., Mizrahi Y., Irrigation, fertilization, and polyethylene covers influence bud development in prickly pear, HortScience 24 (1989) 773-775. 
[15] Nerd A., Karady A., Mizrahi Y., Out-of-season prickly pear: fruit characteristics and effect of fertilization and short drought on productivity, HortScience 26 (1991) 527-529.

[16] Nerd A., Mizrahi Y., Effect of fertilization and organ removal on rebudding in Opuntia ficus-indica (L.) Miller, Sci. Hortic. 59 (1994) 115-122.

[17] Inglese P., Barbera G., La Mantia T., Seasonal reproductive and vegetative growth patterns and resource allocation during cactus pear fruit growth, HortScience 34 (1999) 69-72.

[18] Zegbe J.A., Mena-Covarrubias J., Retraso de la cosecha en nopal tunero cv. Cristalina, Rev. Chapingo serie Hortic. 13 (2008) 85-90.

[19] Crisosto C.H., Johnson R.S., Lunza J.G., Crisosto G.M., Irrigation regimes affect fruit soluble solids content and the rate of water loss of 'O'Henry' peaches, HortScience, 29 (1994) $1169-1171$.

[20] Crisosto C.H., Johnson R.S., DeJong T., Day K.R., Orchard factors affecting postharvest stone fruit quality, HortScience 32 (1997) 820-823.

[21] Ochoa M.J., Leguizamón, G., Uhart, S.A., Effects of nitrogen availability on cactus pear (Opuntia ficus-indica L. Miller) postharvest quality, Acta Hortic. 581 (2002) 225-230.

[22] Medina-García, G., Ruiz-Corral, A., Estadísticas climatológicas básicas del estado de Zacatecas (período 1961-2003), Instituto Nacional de Investigaciones Forestales, Agrícolas y Pecuarias. Libro técnico número 3, México, D.F., 2004.

[23] World Resources Base (WRB), World reference base for soil resources. 2nd ed. World Soil Resources Reports paper 103, Food and Agriculture Organization of the United Nations, Roma, Italy, 2006.

[24] Zegbe J.A., Mena-Covarrubias J., Two reproductive bud thinning alternatives for cactus pear, HortTechnology, 20 (2010) 202-205.
[25] Zegbe J.A., Serna-Pérez A., Mena-Covarrubias J., Mineral nutrition enhances yield and affects fruit quality of 'Cristalina' cactus pear, Sci. Hortic. 167 (2014) 63-70.

[26] Quinn G.D., Keough M.J., Experimental design and data analysis for biologists, Cambridge University Press, Cambridge, United Kingdom, 2002.

[27] Bertin N., Gautier H., Roche C., Number of cells in tomato fruit depending on fruit position and source-sink balance during plant development, Plant Growth Regul. 36 (2002) 105-112.

[28] Wills R., McGlasson B., Graham D., Joyce, D., Postharvest. An Introduction to the physiology and handling of fruit, vegetables and ornamentals, Hyde Park Press, Adelaide, South Australia, 1998.

[29] Corrales-García J., Hernández-Silva J.L., Cambios en la calidad postcosecha de variedades de tuna con y sin semillas, Rev. Fitotecnia Mex. 28 (2005) 9-16.

[30] Cantwell M., Post-harvest management of fruits and vegetable stems, in: Barbera G., Inglese P., Pimienta-Barrios E. (Eds.), Agro-ecology, cultivation, and uses of cactus pear, Plant Production and Protection paper 132, Food and Agriculture Organization of the United Nations, Roma, Italy, 1995.

[31] Maguire K, Banks N.H., Opara L.O., Factors affecting weight loss of apples, Hortic. Rev 25 (2001) 197-234.

[32] Lakshminarayana S., Estrella I.B., Postharvest respiratory behavior of tuna (prickly pear) fruit (Opuntia robusta Mill.), J. Hortic. Sci. 53 (1978) 327-330.

[33] Zegbe J.A., Mena-Covarrubias J., Postharvest changes in weight loss and quality of cactus pear fruit undergoing reproductive bud thinning, J. Prof. Asso. Cactus Dev. 12 (2010) 1-11.

[34] Varela-Gámez Y., Caldera-Arellano A.K., Zegbe J.A., SernaPérez A., Mena-Covarrubias J. 2014. El riego en nopal influye en el almacenamiento y acondicionamiento de la tuna, Rev. Mex. Cien. Agríc. 5 (2014) 1377-1390.

Cite this article as: Jorge A. Zegbe, Alfonso Serna-Pérez, Jaime Mena-Covarrubias. Soil applications of NPK affect fruit quality and shelf-life of 'Cristalina' cactus pear. Fruits 70 (2015) 297-302. 